\title{
A State of the Art of Self Help Groups in India
}

\author{
Shweta Singh, Guido Ruivenkamp and Joost Jongerden \\ Critical Technology Construction (CTC), Research Group of Social Sciences Department, \\ Wageningen University, Wageningen - The Netherlands
}

KEYWORDS Self Help Group. Micro Enterprises. Group Formation. Local Development

\begin{abstract}
This paper considers the strategies of self help group for micro-enterprise development in rural areas. It seeks to answer the question of whether and under which conditions self help groups are an effective vehicle for organizing and representing local people in the development of community based micro-enterprises. Focusing particularly on examples from India in the context of food as a local resource, special attention is paid to success and failure factors of self help groups. While self help group strategies have been applied in the past as a blind replication of success models without considering the intricacies involved in group formation, success of self help groups is based on a thorough understanding of local conditions and possibilities to intervene.
\end{abstract}

\section{INTRODUCTION}

Poverty and unemployment are among the major problems of developing countries, to which India is no exception. In India, according to the Human Development Report (2007), 28.6 per cent of the population was living below the national poverty line and 80.4 per cent of the population was living on (less than) the original UN Development Goal of two dollars a day (PPP), while the Employment and Unemployment Survey Report (2009-2010) estimated the overall unemployment rate at 9.4 per cent. The figures for rural areas are generally worse than those for urban areas. The official rural unemployment rate, for example, is put at 10.1 per cent as opposed to the urban rate of 7.3 per cent, while poverty rates are over 50 per cent higher in rural areas than in urban (GIPC 2010; Alkire and Maria 2010).

In this context, the phenomenon of development oriented Self Help Groups (SHGs) in the Indian context is an interesting issue to investigate. Various experts on developmental issues (poverty, inequality, hunger) have argued that employment opportunities and enhanced income from both farming and non-farming activities are essential for rural economic development and the reduction of rural poverty (Narayanasamy et al. 2003; Kay 2009). Rural communities that are

Address for Correspondence:

Shweta Singh,

Critical Technology Construction (CTC),

Research Group of Social Sciences Department,

Wageningen University,

Wageningen - The Netherlands

Telephone: $91+9811890883$

E-mail: shweta.singh@wur.nl,shweta318@gmail.com well organized have better chances to develop such opportunities, for example by means of selforganization and the generation of community based income generating activities (Gurumoorthy 2000; Barbara and Mahanta 2001).

The employment of SHG programs has emerged as a popular strategy for the facilitation of micro-enterprise development by government, non-government organizations and educational institutes in rural areas in India. These initiatives are not simply the expressions of a neo-liberal politics that favours entrepreneurship and markets as the key for development, they are also the expressions of rural people's needs and interest in their own participation and empowerment (Narayanasamy et al. 2003). Self-help as a strategy for social development emphasises selfreliance, human agency and action (Sabhlok 2006). According to social action theory, people take action towards their goals as groups within the context of their social environment. They have their own, locally defined motives and beliefs, their own interpretations of the meaning of a situation, and they control their own actions (Weber 1991).

Despite great economic and social problems and many constraints in the rural spectrum, various local groups and indigenous organizations have tried to facilitate collective action and coordinated management of (food) systems and the physical environment, and at different spatial scales. As such, the SHG phenomenon can be an important means for alternative development, offering an approach which puts people first is based on collective action. Importantly, SHG strategy has people not as objects of development, but on the contrary as co-agents and sub- 
jects of development. This implies that people have access to and control over resources (Fernandez 1994).

The present study looks at the processes and challenges involved in establishing and implementing the local resource (food) based microenterprises of self help groups. This involves an examination of the role of SHGs in micro-enterprise development, with a focus on their strategies in intervening in local development. In order to prevent blind replication of success models without considering the intricacies involved, it is necessary to critically review experiences. Hence, this study will identify the factors contributing to success or failure so that the strategy (SHG) may be replicated effectively in respect of micro-enterprise development of rural people. A focus is placed on the context of food as a local resource, using India as a geographical study area, and including a focus on village of Mangali in the Hisar district of Haryana state. Indian sources are also emphasised in citations of the literature. We start this article with a short description of the emergence and expansion of self help groups, along with a brief history of the Indian experience. There follows a review of some factors linked to the success or failure of SHGs before discussion of the role of SHGs in micro-enterprise development.

\section{THE EMERGENCE OF SELF HELP GROUPS}

Liberalization, privatization and globalization growth maximizing strategies have virtually isolated the poor, who bear the pain of "development" in the neoliberal focus on macro-economics. During the twentieth century, global average per capita income rose strongly, but with considerable variation among and within countries: indeed, it is clear that the income gap between rich and poor countries and between the rich and poor within each country has been widening for many decades (Sutcliffe 2004; IMF 2002). In India, according to the Human Development Report (2007), the share of income for the richest 10 per cent of population currently stands at 31.1 per cent while the share of income for the poorest 10 percent of population is only 3.6 per cent. In other words, a huge mass of the world's population is excluded from world development, a large of proportion of which (around a third, according to standard poverty figures) is to be found in India. The excluded, which disproportionately means the rural poor, struggle for survival. Their struggle may take different forms, such as peaceful protest movements or popularist economic organizations or it might emerge as the organization of selfhelp movements (Scott 1985; Mitlin and Bebbington 2006; Gledhill 2007).

The self-help movement is said to represent an alternative development strategy, one that involves the process of social economic empowerment and whose long term objective is to rebalance the structure of power in society. It is centred on people and their environments and argues for the rectification of imbalance in social, economic and political power. It is based on a humanist model of development - focused on men and women, and not just on the growth of materials, which are merely means (Friedmann 1992; Elders 2003). In India, for example, the Integrated Rural Development Program (IRDP) has addressed the problem of rural poverty by building the capacities of rural people to plan, drive, and sustain their own social and economic development.

The chief virtues claimed for alternative development are those of "human rights" and "human flourishing" (Friedmann 1992; Reus-Smit 2001) and along with the economic efficiency of financial assistance going directly to the people. Specific aims include building project activity upon intensive face-to-face interaction among stakeholders and developing appropriate technology fine tuned to local conditions, which helps to promote environmentally friendly and sustainable development. SHGs are based on transactive planning, meaning they are oriented towards mutual learning between agents and local actors and based on informal participation, which is crucial for the survival and sustainability of the groups.

The term "development" inevitably refers not only to economic growth, but also to that of local society and its capacity for self-governance directed at the promotion of individual and collective well-being (Carmen 1996; Becattini 2002; Hines 2000; Dematteis 2003; Guevara 2007). Moreover, the development of local societies with independent and differentiated development styles and non-hierarchical networks - is assumed to represent an alternative strategy to economic globalization (Magnaghi 2005). Local sustainable development involves changes in 
the awareness, motivation and behaviour of the individuals in communities, both in the relations between individuals as well as those between groups within a society (Burkey 1993). These changes can come from within individuals and groups through self-help, and not necessarily from outside.

The experiences of self-reliance have led to attempts to build local level organizations like cooperatives, credit societies, neighbourhood or community development associations, water sharing associations and women's groups. Although, the neoliberal paradigm has also incorporated self reliance as a strategy for the building of people's entrepreneurial spirits and their absorption into the capital market (Fernando 2006), SHGs are the offshoots of alternative developments. They are based on the concept of an alternative approach, one grounded in the tenet that development is lived by the people where they live, learn, work, love, play and die. SHGs refer to cooperative activities centred in the community. An SHG is defined as a group or association of individuals with common economic needs who undertake a systematic economic activity, participating directly in decisionmaking and sharing benefits on an equitable basis (Narayanasamy et al. 2003).

SHGs represent a participatory opportunity for social action and empowerment through local people's involvement in identifying and tackling issues that affect their members and communities. The major objectives of building SHGs are to provide members an opportunity and the space to develop a vision/mission and maintain organizational and financial management systems. Other objectives include developing confidence and skills, which help in managing individuals' lives and promoting their interests in the private and public domains, and establishing the linkages required for effective and sustainable institutional function (NABARD 2006; Sabhlok 2006).

\section{THE EXPANSION OF SELF HELP GROUPS}

People's participation in self-help organizations is not new, but a strategy spread across many countries and executed in various location-specific ways. In the areas of urban development and housing, self-help takes the form of neighbourhood groups, tenant groups and slum devel- opment committees, while in rural development, SHGs focus more on the establishment of credit groups, development committees and specific user groups. In East Africa (for example, Kenya), for example, the tradition of local self-help development efforts, or harambee, is characterized by local initiatives to control and collectively work to use local resources focused on rural development (Thomas 1985). In Southeast Asia (for example, Vietnam), the Tontine or Hui (also Hawala or Fei Chein) tradition of SHGs focuses on financial activities through cash or kind (Abiad 1995), while self-help efforts in Indonesia, are also organized around credit unions and village-based banks, with some SHGs composed of fishermen and irrigation groups (Gaonkar 2004).

Generalised as Rotating Savings and Credit Associations (ROSCA), the SHG function of locally provided, organised material support or, informal banking - has been seen as a "middle rung in development", historically contextualised by peasant social structure (Geertz 1962). In recent times, however, it has been given a new lease of life with the concept of microcredit, the extension of small loans to support the entrepreneurial ambitions of the poor, those least able to gain access to capital. The specific SHG form of microcredit groups has been set up in different countries in the South now. The Grameen groups in Bangladesh are the most well-known example of this phenomenon, and various microcredit groups have also been formed in other countries in the region, such as in Thailand, Nepal and Sri Lanka, as well as in India where SHG's have been helping to set up micro-enterprises for income generation.

The alleged success of such schemes - in general, about 95 per cent of microcredit recipients pay back their loans (Cohen 2001) - has led to the perception of microcredit borrowers as prebankable, a potentially lucrative market for the banking sector to exploit (rather like students in the rich countries). It has also facilitated social targeting within the general class of the poor, most notably of the rural poor and of women and women's groups. Against this, however, microcredit has also been criticised, among other reasons for tending to operate only around the border of poverty (especially helping people with pre-existing businesses) rather than in its deeper reaches, and for typically offering a onedimensional support (financial credit) without 
other services (Islam 2007). Thus, for example, a study of the gender aspect of micro financing in the South Indian context (Holvoet 2005) leads to an argument for the need for financial and social group intermediation as part of the microcredit input so as to support women's involvement in decision making processes.

\section{SHGS IN INDIA}

The SGH microcredit approach in India was first developed through the Self-help Affinity Groups facilitated by the Mysore Resettlement and Development Agency (MYRADA) in 1985, since which more than two million self help groups have been created across the country (NABARD 2005-2006). In 1986-87, there were about 300 SHGs in Myrada's projects, many of which had emerged from the breakdown of large cooperatives because of lack of confidence in the leadership and poor management. In areas where the cooperatives had broken down, several members (usually in groups of 15-20 people) approached Myrada requesting it to revive the credit system. When reminded about the loans they had taken from the cooperatives, they offered to return them to Myrada but not to the cooperative which, in their experience, was dominated by a few. Myrada staff realized that they would need training on organising meetings, and so efforts were made to train the members in a systematic way. From an analysis of these members's activities, (Fernandez 2006), it emerged that they were linked by a degree of affinity based on relations of trust and support. They tended also to be homogeneous in terms of income and occupation (for example, agricultural labourers). Caste and creed played a role, but in several (caste/creed) mixed groups affinity relations and economic homogeneity were stronger.

The real effort to support SHGs in India, however, came in the late 1990s when the central government of India introduce a holistic program, Swarnjayanti Gram Swarozgar Yojana (SGSY) based on the group approach for rural development. The SGSY approach was to encourage the rural poor to organize themselves into SHGs and to independently take up viable economic activities as micro-enterprises with support from government subsidies and bank credit (Tripathy 2004). This SHG strategy has become an important component of the Government of India, in- cluded in every annual plan since 2000. Follow up for SHGs is provided by the Indian Banks Association, State-Level Bankers Committees, District Consultative Committees, Sponsor Banks, the National Bank for Agriculture and Rural Development (NABARD), facilitating NGOs and appointed research teams and research institutions. Indian SHG self-help guides have been developed and are now available free of charge on the Internet, including, for example, a training manual aimed at SHG formation in the rural context (NABARD 2009), and a workshop instruction manual for SHGs oriented to microenterprise, produced by the Haryana Community Forest Project (HCFP 2003).

In case of the Hisar district of the state of Haryana, in northwestern India, 500 SHGs have been registered under the SGSY and promoted by the District Rural Development Authority (DRDA), engaged in bead-making, shoe-making, dairy, and tailoring and embroidery, while over 1200 SHGs are currently working under the Supplementary Nutrition Program of Integrated Child Development Scheme (ICDS), responsible for the preparation of food items (National Informatics Center, Hisar 2008). Specifically in the village of Mangali, employed by way of case study, ten SHGs were found to be working under DRDA and ten under ICDS in the areas described. Upon investigation, it was learnt that the people in these SHGs were hoping to generate additional income (and make savings) in order to enhance the economic condition of their families. They explained that the economic benefits, personal interest and psychological benefits (satisfaction due to increased status in the family or community) that they have received were the key factors in the sustainable management of microenterprises. However, they also stated that the non-availability of raw materials and poor access to markets for product sales were key issues which need to be addressed if the microenterprise development is to be sustained.

Intended to strengthen viable, small businesses, resulting in increased household income and savings, and thus alleviating the crunch of economic poverty (World Vision India 2009), micro-enterprise development (MED) aims at building self-esteem and self-reliance, encouraging autonomy and creating a community atmosphere (Geroy et al. 1997). It builds economic capital by creating jobs and generating income, ultimately working towards community development in impoverished or unemployed areas 
(Clark and Huston 1993; Clark and Kays 1995 and 2000; Edgcomb et al. 1996; Servon 1998).

\section{KEY FACTORS IN SHG CONTRIBUTION TO DEVELOPMENT}

Self-help as a strategy for social development places emphasis on self-reliance, human agency and action. It aims to mobilise people, to give them a voice and to build people's organisations that will overcome barriers to participation and empowerment. Central to the idea of self-help is the formation of groups, the concept of a 'community' and the development of egalitarian relationships that will promote people's well-being (Sabhlok 2006). Social action theory (Weber 1991) stresses the ability of individuals to exert control over their own actions. People are not passive receptacles of society's directives, but active creators of social behaviour. They have their own motives and beliefs, and their own interpretation of the meaning of a situation. These all need to be integrated into SHGs for them to thrive.

There are several factors that contribute to success or failure in the functioning of the SHG, and which may thereby facilitate or otherwise the development of micro-enterprises. Singh and Jain (1995) identifies factors which have an impact on group formation, namely, the full participation of all members, homogeneity among members, and transparency in group all operations and functioning (which promotes trust, mutual faith and confidence). Considering women's self-help groups in Andhra Pradesh, Ranadive (2004) shows that people's participation at every level of decision making within the program transforms beneficiaries into participants, from which ultimately everyone benefits. Anand (2002) argues that homogeneity in membership (members belonging to the same income or social strata) contributes also to group success. Suguna (2006) argues that people with a similar social background exhibit similar coping behaviours in times of stress and will thus be able to extend mutual support.

Other success factors include clearly defined goals (knowing what is expected), and an established structure or accepted process of well-defined steps that include schedules, breaks, feedback periods, regular information up-dating (goals and other pertinent information) and a clearly understood delegation of tasks to be ac- complished (clear and simple directives). A group goal is a future state of affairs desired by enough members of the group to motivate the group to work toward its achievement (Johnson and Johnson 2006). DeLucia-Waack et al. (2002) summarize what is needed to ensure the effectiveness of groups thus: "Research shows that group goals must be clearly defined, leaders must have specific leadership training and skills, and they must take into consideration member expectations about the group, willingness to participate, and cultural expectations and values when designing a group and implementing specific intervention." An understanding of the goals of the group and the reason for its existence elicits contributions based on the needs of the group, i.e. participation. And this participation is most effective when the members are fully aware that their contributions must be oriented towards the advancement of the group (CAP Santé Outaouais 2009).

A key element of the SHG approach, participation refers to the involvement by local populations in the creation, content and conduct of a program to change their lives. It requires the recognition and usage of local capacities, and must avoid the imposition of priorities from the outside. Three separate studies of participatory program by the World Bank (1996), the Canadian International Development Agency, CIDA (1997) and the United states Agency for International Development, USAID (1999) have found participatory development programs to be more relevant and effective at addressing local needs. Moreover, the gains made during an intervention program are more often sustained using participatory methods, and it is more likely that the engagement of local people in the intervention process will improve their economic status (Jennings 2000). Similarly, Gurumoorthy (2000) maintains that SHGs are a viable alternative in order to achieve the objectives of rural development and elicit community participation in all rural development programs.

Shylendra (1998) evaluated the performance of eight women SHGs promoted in the village of Vidaj in the western state of Gujarat by the Institute of Rural Management, Anand (IRMA). The main lessons drawn from this project were the necessity of (1) creating SHGs based on a clear assessment of the needs of different sections of the society, (2) ensuring a clear understanding of the concept of SHG among team members 
involved in promoting SHGs, and (3) enhancing the relevance of SHGs by enabling members to meet their requirements effectively.

Bakshi (1995) looked at the organizational structure of informal, grass-root level women's groups at Alappuzha (a small coastal town in the southern state of Kerala), with informal neighbourhood groups (NHGs) in the small hamlets, later federated into Area Development Societies (ADS) at the ward level and linked to the Community Development Society (CDS) at town level for empowering the poor. CDS focuses on a variety of health, education, housing, poverty, etc. issues as determined by a bottom-up needs-based planning process based on the three-tier SHG system. This, thus, represents an organizational model for informal groups in a rural area and effective people's participation in management. Among the important features of this model as specified by Bakshi are the development of appropriate indicators with which to identify poor people and their basic and current needs, decision making in the common interest, group planning and management of financial activities, the convergence of resources, and skill development and empowerment through participatory learning methods. Also related to the issue of participation and organisational structure, Guevara et al. (2008) has considered the local perceptions on empowerment and development in a small village from Chiapas, Mexico, emphasizing that interveners should pay close attention to the outcomes of village self-assessments in order to guide future actions. This also encourages villagers to critically review their own situations.

Narayanaswamy et al. (2005) argues that sometimes group activities do not provide enough space for people to participate. Among those who participate, one or two dominate. A conflict among members tends to arise as a result of this, leading to a waning of interest and even group disintegration. Guevara (2007) draws attention to leaders' roles as settlers, linkers, motivators, facilitators, and negotiators. At the same time, however, the participatory imperative implies that leadership should rotate according to the resource framework of the group.

Linked to the issue of leadership and political organisation of groups, the APMAS/EDA (2006) study of Indian SHGs reported the problem of dropout among members, revealing the need of clear norms related members' organisational behaviour. SHGs, it is suggested, may discuss and finalize a set of by-laws, indicating rules and regulations for group functioning as well as roles and responsibilities of members. In this respect, Olivier de Sardan (2004) suggest that "the maneuvers, intrigues, influence struggles, monopolizations, the rhetoric and manipulations, come from all sides." There is thus a need to take into account the collaboration and complicity of marginal actors, to analyze how the so-called 'beneficiaries' understand and manipulate the rhetoric, rules, and rewards of aid delivery (Mosse and Lewis 2006).

In above view of all these different experiences and (sometimes diverging) results, a special consideration of factors contributing to micro-enterprise development and support by SHGs that reflects on their strengths and weaknesses is indicated in order to build and improve the SHG/ micro-enterprise model.

\section{MICRO-ENTERPRISE AND SHGS}

Development in rural areas is confronted with a wide range of problems grounded in the very poverty that it seeks to tackle. Issues related to extreme and chronic poverty around areas like poor income, low levels of education and a lack of awareness of developmental options are among the challenges facing SHGs as they organize themselves as specific micro-enterprises (NABARD 2006). More specific areas of concern revolve around entrepreneurship, to which the micro-credit movement is addressed. Factors contributing to micro-enterprise development and support by SHGs are reviewed here under the headings of finance, training and skills development, mobilization and representation of local people, target group approach, and marketing and technology support.

\section{Finance}

A rural micro-enterprise promotion program developed for the Philippines and other countries in the region (COSOP 1999) reviewed the ways in which financial needs are addressed. The conclusion of this paper was that the formal sector banking network and institutionalization of agriculture and rural credit rarely provide access for the poor in India. Thus, the rural poor turn to the informal sector for their credit needs, principally to traders, moneylenders and landlords which results in exploitation, leading in turn to 
the development of various group-based microfinance schemes aimed at providing credit to the poor. It was also argued that financial services are needed in addition to suitable access to credit, as well as non-financial business services such as skills, training and technology transfer, market access, better market and pricing information and insight into the functioning of local markets.

Concerning the capital shortages and inadequate access to financial services for both agricultural and non-farming activities, various micro-enterprises has been set up in India to challenge the long-standing problem of sustainable local financing. SHGs provide the financial (saving and credit) services as financial intermediaries in a cost effective and sustainable manner to facilitate the access for the rural poor and attenuate risks. Included as a crucial element in the poverty alleviation measures for 1996-2006, SHG banking in India has grown to become the developing world's largest microfinance program for the rural poor, comprising around 2.2 million SHGs with a total of 33 million (selfselected) members, 90 percent of them women, credit-linked to some 36,000 bank branches and cooperative societies. The NABARD SHG-bank linkage program (essentially a central development bank financing local SHG banks) benefited four million families covering an estimated 20 million poor (NABARD 2006).

\section{Training and Skills Development}

Another crucial aspect for micro-enterprise development is capacity building, the process by which individuals, groups, institutions, organizations and societies enhance their abilities to identify and meet development challenges in a sustainable manner (CIDA 1996; Morgan and Qualman 1996). Hagmann (2000) describes how an effective vehicle for capacity building development has proven to be the joint development of technical and social innovations by local people with external agents, based on a synthesis of indigenous and scientific knowledge. Capacity in terms of micro-entrepreneurship depends on community, social-economic environment, the nature of business, market and entrepreneurial skills (Sapovadia 2007). Indian SHGs are generally found to be very effective in organizing the informal education and training (for example, entrepreneurial and technical training) programs for the exchange and sharing of knowledge and skills of the rural folk. Many NGOs, government programs and micro-finance institutions organize training programs for SHG members and leaders. Training and Technologies Development Centres (TTDC) are one of the examples of a body aiming to introduce innovative technologies for the qualitative improvement of the products made by the SHGs. Other examples include the Stree Shakti programme in the dairy cooperative sector in Madhya Pradesh, the training-cum-employment programme for women the Women's Economic Program, the Swa-Shakti Project, Rashtriya Mahila Kosh and others (Sardana 2002; Adolph 2003).

It is not clear what proportion of SHG members in India have benefited from such training and what proportion of trainees has been able to make use of this training by starting a micro-enterprise. Moreover, training alone is not enough to ensure that group members take up micro-enterprise - their success depends also on markets for the services and goods produced (Adolph 2003).

\section{Mobilization and Representation of Local People}

Miller and Grace (1990) argued for the creation of a systematic learning approach to micro-enterprise development. They believe that learning is not the simple acquiring of skills in order to achieve objectives, but a process of fulfilling the need for self improvement. Further, they suggest a micro-enterprise learning system should include experiences which (1) focus on problem-oriented issues, (2) have a direct relationship to need and use, (3) stress measurable performance that can be positively reinforced, and (4) emphasize experiential activities. Assuming a SHG approach, these involve the representation of local people, thereby building participatory oriented organisations contributing to the development of micro-enterprise and enhancing its effectiveness in rural areas. Moreover, SHGs intrinsically involve participation and decision making processes that foster local development.

\section{Target Group Approach}

Liedholm and Mead (1999) argue that rural organizations and the representation of rural in- 
terests are important, and that among the array of small enterprises there are various target groups, each with different contributions and with different support needs. Steel (1994) reveal that for women as entrepreneurs in the rural areas, gender stereotyped perceptions of self, a lack of confidence and assertiveness, appear to be major barriers, but the SHG strategy contributes to women's empowerment through income generating and capacity building activities and provides space to participate in groups, avail new ideas and develop self-confidence that facilitates women's entrepreneurial capacities.

Shri Mahila Griha Udyog Lijjat Papad, or Lijjat, is an example of an organization that has engaged in empowering poor women across India, as well as evidencing the growth potential of micro-enterprise. Starting as a small group of seven women in 1959, today Lijjat has more than 40,000 members in 62 branches across 17 Indian states. The word 'mahila' means woman in the Gujarati language, 'griha udyog' stands for cottage industry, 'lijjat' (the brand name) means tasty, and 'papad' is a thin, round savoury snack. The women maintain high production standards, a practice which has turned out to be their main strength. The target group approach in this case was by word of mouth and advertising in a local newspaper, which contributed to the rapid growth of the group. Subsequently, the target group was attracted by the economic benefits and SHG values of the organisation. In most families of Lijjat members, the wives' monthly earnings are a valuable addition to the total family income, and this has enhanced their status and power within the family, while Lijjat follows principles of self-reliance and trust, and all members have equal rights (Bhatnagar et al. 2009).

Other interesting examples of SHGs in microenterprise development in India include Okhai, Lohardaga and Meerut Sewa Samaj. 'Okhai' refers to a village (Okhamandal) in Gujarat state, where rural women ubiquitously practice and pass down traditional handicraft skills, such as mirror work, patchwork, embroidery and appliqué work. The Okhai enterprise was initiated by the Tata Chemicals Society for Rural Development (TCSRD) in 2002, a body that organizes training in making traditional designs appealing to consumers (the market) along with workshops on teamwork, quality issues and marketing to strengthen women's practical business know how. They have partnerships with other organizations such as Tata, National Institute of Fashion Designing (NIFT) and Sasha (Sarba Shanti Ayog). They focus on quality of products. They sell their products through exhibitions in cities such as Delhi, Mumbai, Pune and Ahmadabad.

Lohardaga is also a village name, a community in the eastern state of Jharkhand where a dairy program was initiated in $2004-05$ by the state government for farmers. Since, more than 700 farmers have been involved in dairy activities, producing milk and dairy products such as cheese, yoghurt and cottage cheese. Meerut Sewa Samaj is a village level organization which makes beaded jewellery such as belts, bracelets and necklaces. Market linkages are developed by a member of the organization, who visits local markets with product samples to obtain orders. Orders are distributed among the members of the organization. This program has been successful and other businesses have been developed in nearby villages in other product areas, such as textiles, weaving, handicrafts, bangle decorations and bee keeping (Herschel 2009).

\section{Marketing and Technology Support}

An important aspect of micro-enterprises is the access to local market, or, in other words, the ability of the resource-poor to challenge the lack of access to the local market and to its marketing services (Aheeyar 2007). Aheeyar states that problems related to marketing and obtaining a reasonable price for products badly constrain the majority of the clients. He also reports that 40 to 50 percent of the enterprises have failed due to problems related to marketing. Competition is seen in marketing of the products which have been pioneered by the retailers, supermarkets and other marketing agencies. This coupled with lack of knowledge on business management, and inadequate resources and support mechanisms reduce the development perspectives of the microenterprises (Kibas 2005). In this respect, local organizations (SHGs) have to depend on marketing agencies as promoters for marketing of their products - which invites the suggestion that SHGs work as integrated networks of local people, where people share the responsibilities of product packaging and distribution.

The entry of non-SHG enterprise into the SHG-market relationship means a loss of revenue for the micro-enterprises. Local people 
should be able to sell directly to the consumers and avoid the huge markup taken by middle marketing agencies. Thus, special attention needs to be given to (re-)linkages with market, which should be created locally. Additionally, to stay competitive backward linkages with information technology is important. Edgcomb et al. (1996) place a stress on workable information systems that facilitate work and provide timely and needed information. SHGs might contribute as sites where people gain (information) technology in their local settings (environment).

Ganpathi and Malar (2008) emphasize reasonable and affordable product prices are an important factor influencing consumers to buy from SHGs. Purchasing decisions are also influenced by factors like service, quality, value for money and the homemade nature of the products. Customers are reported to feel that product packaging needs to be improved. Jose and Nair (2011) point to another marketing shortfall, that SHG products are not getting enough advertisement. These two points combine in the criticism that most of the products are not branded, properly processed or sealed - due to the lack of appropriate technology - and sales take place only in the immediate vicinity.

In respect of marketing, Karuppasamy (2010) suggests that the government should arrange presentation and advertising training programmes, and that the government channels might broadcast the SHP advertisements at minimal or no charge. The technology indicates a needs analysis. Abrol (2003) lists the key domains for effective technology implementation as:

- Identification of the needs of peasants and agricultural labourers as producers

- Adaptation of technologies to make items/ products fully competitive in local markets

- Formation of production networks to establish forward and backward linkages within the local economy area, thus strengthening the competitiveness of the local system.

\section{CONCLUSION}

This review of the role of SHGs in micro-enterprise development suggests that SHGs engaged in building successful micro-enterprises in India generally need to be able to fulfil the needs of finance, training and skills development. How fast the SHGs can move forwards and become a sustainable strategy for alternative de- velopment organized by people themselves also depends on their ability to intervene in and change the circumstances in which they live and develop new production and market relations.

An imperative challenge is to create linkages with markets by local people of local organizations (SHGs) in such a way that they will receive a higher share in the value developed. Further research might identify more opportunities and analyse exemplary practices of SHGs.

\section{ACKNOWLEDGMENTS}

The authors thank the North - South Interdisciplinary Research and Education Fund (INREF) of Wageningen University in the Netherlands that initiated this research through a project named TELFUN: Tailoring food sciences to Endogenous patterns of Local food supply for Future Nutrition. The authors also thanks the Department of Biotechnology of the Government of India provided partial funding for this research.

\section{NOTES}

1.The povertyfigures are interpretive, of course: the (20042005) proportion of people living below the poverty line, for example, has recently been revised upwards from 28.6 to 37.2 per cent by the Tendulkar Report (GIPC 2010), while the Multidimensional Poverty Index developed by the Oxford Poverty and Human Development Initiative puts the proportion of poor people in India at 55 per cent. Tenduldar's 37 per cent poverty figure is composed of 26 per cent for urban areas and 42 per cent for rural areas (GIPC 2010). See also the MPI graphic (Alkire et al. 2010).

2. The IRDP established in 1978, the Indian IRDP was a credit based system co-funded by central and state governments, now merged with other programmes as Swarnjayanti Gram Swarozgar Yojana (SGSY), a "holistic self-employment scheme". See http:// rural.nic.in/i1.htm.

3. The NGO Myrada now manages rural development programmes directly serving some 8.5 million people in three states of southern India and provides on-going support including deputations of staff to programmes in six other states as well as promoting the SAG strategy in Cambodia, Myanmar and Bangladesh. 'Building poor people's institutions' is its short mission statement, with the objective being to help the poor help themselves. An emphasis is placed on environmental, sanitation and drinking water, housing and education, and preventative health care (including HIV/AIDs) issues. Institutionally, in addition to promoting SAGs, Myrada focuses on support for similar local level bodies (in line with its policy emphasis), district level network building, and micro-enterprise generation (through Sanghamithra, a microfinance institution that lends directly to SHGs). See www.My rada.org. 
4. NABARD states 'effective credit support' as one of its methods of 'promoting sustainable and equitable rural and agriculture development'. See http://www.nabard. org/index.asp.

5. HCFP aims to "conserve and rejuvenate natural resources, mainly through forestry development, with the active participation of communities, especially women', the Haryana Community Forest Project has produced various manuals emphasizing participation, gender perspectives, etc. See http://hcfp.gov.in/.

6. IRMA aims to "promote sustainable, ecologically-friendly and the eqýitable socio-economic developmemt of rural people through professional management", to which ends it provides management training programmes, and also supports local cooperatives, and works with other agencies. See https://www.irma.ac.in/index.php.

\section{REFERENCES}

Abiad V 1995. Grassroots Financial System Development in Vietnam. Bangkok: APRACA Consulting Services.

Adolph B 2003. The role of self help groups in rural nonfarm employment. Rural non- farm economy: Access factors. Discussion Paper. Natural Resource Institute. University of Greenwich, Medway, United Kingdom.

Aheeyar MMM 2007. Impact of micro-finance on microentrepreneurs: A comparative analysis of Samurdhi and SEEDS micro-entrepreneurs in Sri Lanka. Research Report 117, Hector Kobbekaduwa Agrarian Research and Training Institute (HARTI) Colombo, Sri Lanka.

Alkire S, Maria E S. 2010. India Country Briefing. Oxford Poverty and Human Development Initiative (OPHI) Multidimensional Poverty Index Country Briefing Series. From <www.ophi.org.uk/policy/multidimen sional-poverty-index/mpi-country-briefings/> $(\mathrm{Re}-$ trieved August 20, 2011).

Anand Jaya S 2002. Self-help Groups in Empowering Women: Case Study of Selected SHGs and NHGs. Discussion Paper 38, Kerala Research Programme on Local Level Development Centre for Development Studies, Thiruvananthapuram, Kerala, India.

APMAS/EDA 2006. Self Help Groups in India. A Study of Lights and Shades. Andhra Pradesh Mahila Abhivruddhi Society, Hyderabad and Rural Systems Private Ltd., Gurgaon.

Abrol D 2003. Embedding technology in community- based production systems through people's technology initiatives: Lessons from the Indian experience. International Journal of Technology Management and Sustainable Development, 1: 1-28.

Bakshi P 1995. Empowering the poor women for community development: A unique programme in Alappuzha town of Kerala. Vikalpa, 20: 3-6.

Barbara S, Mahanta R 2001. Micro finance through self help groups and its impact: A case of Rashtriya Gramina Vikas Nidhi - Credit and saving programme in Assam. Indian Journal of Agricultural Economics, 56(3): 43-51.

Becattini G 2002. Le condizioni dello svilluppo locale. Supplement to La Nuova City: Florence.

Bhatnagar D, Rathore A, Torres M, Kanungo P 2009. Empowering women in urban India: Shri Mahila Griha Udyog Lijjat Papad. From <http://siteresour
ces.worldbank.org/INTEMPOWERMENT/Resour ces/14652_Lijjat-web.pdf> (Retrieved May 17, 2009).

Burkey S 1993. People First: A Guide to Self-Reliant Participatory Rural Development. London: Zed Books.

CAP Santé Outaouais 2009. Self-help: How-to Manual for Self-help Groups. From <www.capsante-outaouais. org/english/self-help-web/effectiveness.html> (Retrieved May 15, 2009).

Carmen R 1996. Autonomy Development: Humanism the landscape. London: Zed Books.

CIDA PB 1996. Capacity Development: The Concept and its Implementation in the CIDA Context. Hull: CIDA.

CIDA 1997. Mainstreaming Participatory Development: Experiences and Lessons of the Interagency Group on Participation. Hull: CIDA.

Clark P, Huston T 1993. Assisting the Smallest Businesses: Assessing Microenterprise Development as a Strategy for Boosting Poor Communities. Washington, DC: The Aspen Institute.

Clark P, Kays A 1995. Enabling Entrepreneurship: Microenterprise Development in the United States. Baseline Year Report of the Self-Employment Learning Project. Washington, DC: The Aspen Institute.

Cohen N 2001. What Works: Grameen Telecom's Village Phones. Dhaka: World Resource Institute.

COSPOP 1999. Rural Micro-enterprise Promotion Program. Country Strategic Opportunities and Inception Paper. Manila, October 29 to November 6, 1999.

Dematteis G 2003. Per una geografia della territorialita attia e dei valori territorial. In: Bonora P. (Ed.): SloT, Quaderno I. Bologna: Baskerville.

DeLucia-Waack J, Bridbord KH, Kleiner J 2002. Group Work Experts Share Their Favorite Activities: A Guide to Choosing, Planning, Conducting, and Processing. Alexandria, VA: Association for Specialists in Group Work.

Edgcomb E, Klein J, Clark P 1996. The Practice of Microenterprise in the U.S.: Strategies: Costs and Effectiveness. Washington, DC: The Aspen Institute.

Elders JL 2003. Humanism. Its Roots and Development. What Humanism Consists of? Paper presented in Congress Tomista International, Pontificia University di San Tommaso Angelica, Roam, September 21 to $25,2003$.

Employment and Unemployment Survey Report 20092010. Ministry of Labour and Employment, Government of India. From <http://labourbureau. nic.in/Final_Report_Emp_Unemp_2009_10.pdf $>$ (Retrieved January 7, 2011).

Fernandez AP 1994. The Myrada Experience: Alternate Management Systems for Savings and Credit of the Rural Poor. Bangalore: MYRADA.

Fernandez AP 2006. History and Spread of Self- help Affinity Group Movement in India. Discussion Paper 3. Asia and Pacific Division. Rome: IFAD.

Fernando JL 2006. Perils and prospects of micro-credit: Neoliberalism and cultural-politics of empowerment. Routledge Studies in Development Economics. London: Routledge.

Friedmann J 1992. Empowerment: The Politics of Alternative Development. Cambridge: Blackwell.

Gaonkar R 2004. Role of Self-help Groups in Empowerment of Women. Paper presented at the ISTR Sixth 
International Conference, Toronto, Canada, July 11 to $14,2004$.

Ganpathi R, Malar AS 2008. Consumers attitude and preferences towards self help groups products. Asiapacific Business Review, 4(3): 18-25.

Geertz C 1962. The rotating credit association: A middle rung in development. Economic Development and Cultural Change, 10(3): 241-263.

Geroy DG, Jankovich J, Thomas J, Hyden JT, Wright CP 1997. HRD and microenterprise: Socio-economic capacity building in LDCs. Empowerment in Organizations, 5(2): $65-75$.

GIPC 2010. Report of the Expert Group to Review the Methodology for Estimation of Poverty. Government of India Planning Commission, 2009. From <http:// planningcommission.nic.in/reports/genrep/rep_pov. pdf $>$ (Retrieved August 20, 2011)

Gledhill J 2007. Indigenous movements in Mexico: Impasse or forward motion?" In: Jessica Perkins, Karen Campbell (Eds.): Across Borders: Diverse Perspectives on Mexico, Toronto: ISC Mexico, pp. 99-116.

Gurumoorthy TR 2000. Self help groups empower rural women. Kurukshetra, 2: 26-32.

Guevara HF 2007. Y después qué?: Action-research and Ethnography on Governance, Actors and Development in Southern Mexico. Ph.D. Dissertation, Wageningen University, Netherlands. From <http:// library.wur.nl/wda/dis sertation/dis4298.pdf > (Retrieved January 2, 2011).

Guevara HF, Pinto RR, Gomez CH and Medina JJF 2008. Local perceptions on empowerment and development in a remote village of Chipas, Mexico. Tailoring Biotechnologies, 4(1-2): 71-74.

Hagmann J 2000. Learning Together for Change: Facilitating Innovation in Natural Resource Management Through Learning Process Approaches in Rural Livelihoods in Zimbabwe. Volume 29. Weikersheim (Germany): Margraf.

HCFP 2003. Training Manual on Self-Help Groups for Micro-Enterprise Development. Panchkula, Haryana: Haryana Community Forestry Project. From <http:// hcfp.gov.in/downloads/manuals/Training_Manual on_SHG_For_Micro-Enterprise_Development.pdf $>$ (Retrieved August 24, 2011).

Herschel S 2009. Impact Assessment of SHGs with a Specific Focus on the Need for Market Linkages and the Business Professionalization. MBA Dissertation. Judge Business School. University of Cambridge. Tata Steel Rural Development Services Jamshedpur, Jharkhand.

Hines C 2000. Localization: A Global Manifesto. London: Earthscan Publications.

Holvoet N 2005. The impact of microfinance on decisionmaking agency: Evidence from South India. Development and Change, 36(1): 75-102.

Human Development Report 2007. Country Fact SheetsIndia. From <http://hdrstats.undp.org/ countries/ country_facts_sheets /cty_fs_IND.html> (Retrieved August 25, 2008).

IMF 2002. World Economic Outlook Staff Studies, Globalization: Threat or Opportunity? From <www. imf.org/external/np/exr/ib/2000/041200to.html> (Retrieved October 15, 2008).

Islam T 2007. Microcredit and Poverty Alleviation. Aldersho, UK: Ashgate Publishing Ltd.
Jennings R 2000. Participatory Development as New Paradigm: A transition of development professionalism. Prepared for the Community Based Reintegration and Rehabilitation in Post-conflict Settings Conference in Washington, DC, October 2000.

Johnson DW, Johnson F 2006. Joining Together: Group Theory and Group Skills. $9^{\text {th }}$ Edition. Boston: Allyn and Bacon.

Jose S, Nair LV 2011. Women SHG in coastal Kerala: The lopside of social development. International Journal of Sociology and Anthropology, 3(20): 56-60.

Kay C 2009. Development strategies and rural development: Exploring synergies eradicating poverty. The Journal of Peasant Studies, 36(1): 103-137.

Karuppasamy S 2010. Marketing of Products Produced by Self Help Groups. From <http://EzineArticles. com/ ?expert=Suresh_Karuppasamy (Retrieved January 5, 2011).

Kibas Peter B 2005. Challenges Facing Women Entrepreneurs. Paper presented at the Third Africa Resource Bank Meeting, Nairobi - Kenya, November 27 to $30,2005$.

Liedholm CE, Mead DC 1999. Small Enterprises and Economic Growth: The Dynamics of Micro and Small Enterprises. London: Routledge.

Magnaghi A 2005. The Urban Village: A Charter for Democracy and Local Self-Sustainable Development. London and New York: ZED Books.

Miller HG, Grace L 1990. Global aspects of local micro enterprise development. Journal of Studies in Technical Careers, 12: 27-37.

Mitlin D, Bebbington 2006. Social Movement and Chronic Poverty Across the Urban-Rural Divide: Concepts and Experiences. CPRC Working Paper 65. Institute of Development Policies and Management, Manchester, UK.

Morgan P, Qualman A 1996. Applying Results-Based Management to Capacity Development. Hull: Branch, CIDA.

Mosse D, Lewis D 2006. Theoretical approaches of brokerage and translation in development. In: D Lewis, D Mosse (Eds.): Development Brokers and Translators: The Ethnography of Aid and Agencies. West Hartford CT (United States): Kumarian Press, pp. 1-26.

NABARD 2005-2006. National Agricultural Bank for Rural Development, Annual Report. Mumbai, India.

NABARD 2009. A Handbook on Forming Self-Help Groups (SHGs). From <http://indiamicrofinance. com/self-help-group-formation-training-manualnabard.html> (Retrieved August 20, 2011).

Narayanaswamy N, Manivel S, Bhaskar B 2005. Microcredit: Driven rural enterprises-lessons from SHGs assisted under SGSY scheme. Journal of Rural Development, 24(3): 356-376.

National Informatics Center, Hisar (Haryana). From <http:/ /www.hisar.nic.in> (Retrieved November 22, 2008).

Olivier de Sardan JP 2004. Anthropology and Development: Understanding Contemporary Social Change. London: Zed Books.

Ranadive DJ.2004. Women's Self Help Groups in Andhra Pradesh- Participatory Poverty Alleviation in Action. A Case Study from Reducing Poverty, Sustaining Growth-What Works, What Doesn't and Why? Scaling Up Poverty Reduction: A Global Learning Process and Conference in Shanghai, May 25 to 27, 2004. 
Reus-Smit C 2001. Human rights and the social construction of sovereignty. Review of International Studies, 27(4): $519-538$.

Sabhlok SG 2006. Self-help as a Strategy for Women's Development in India. Paper presented in 16th Biennial Conference of the Asian Studies Association of Australia in Wollongong, The University of Melbourne, Australia, June 26 to 29, 2006.

Sapovadia Vrajlal K 2007. Poverty Reduction Strategies Through Cooperatives. Working Paper Series. Indore: Indian Institute of Management.

Sardana CK 2002. Capacity Building for Entrepreneurship. Delhi: Press Information Bureau, Government of India.

Scott James C 1975. Weapons of Weak: Everyday Form of Peasants' Resistance. New Haven Conn.: Yale University Press.

Servon L 1998. Credit and social capital: The community development potential of U.S. microenterprise programs. Housing Policy Debate, 9(1): 115-149.

Shylendra HS 1998. Promoting Women's Self-Help Groups: Lessons from an Action Research Project. Working Paper 121. Institute of Rural Management, Anand (Gujarat).

Singh K, Jain TSR 1995. Evolution and Survival of SHGs: Some Theoretical Proposition and Empirical Evi- dences, Working Paper 4. Bankers Institute of Rural development, Lucknow.

Steel WF 1994. Changing the institutional and policy environment for small enterprise development in Africa. Small Enterprise Development, 52: 4-9.

Suguna B 2006. Empowerment of Rural Women Through Self Help Groups. New Delhi: Discovery Publishing House.

Sutcliffe B 2004. World inequality and globalization. Oxford Review of Economic Policy, 20(1): 15-37.

Thomas B 1985. Politics, Participation, and Poverty: Development through Self-help in Kenya. Boulder, USA: West view Press.

Tripathy KK 2004. Self help groups: A catalyst of rural development. Kurukshetra, 52(8): 40-43.

USAID 1999. Participation at USAID: Stories, Lessons and Challenges. USAID Participation Forum Summaries. New York: USAID.

Weber M 1991. The Nature of Social Action in Runciman, W.G. Weber: Selections in Translation. Cambridge: Cambridge University Press. pp.1-7.

World Vision India. Building up rural India- Alleviating poverty. From <www.worldvision.in> (Retrieved May 15, 2009).

World Bank 1996. The World Bank Participation Sourcebook. Washington: World Bank. 